Katarzyna Juszczyk-Frelkiewicz

Uniwersytet Śląki w Katowicach
Kiedy myślimy Rodzina..., red. M. Duda,

K. Kutek-Sładek, Kraków 2016, s. 9-23

(Praca Socjalna w Teorii i Działaniu, 2).

DOI: http://dx.doi.org/10.15633/9788374385091.02

\title{
Rodzina współczesna - dysonans pomiędzy preferowanym modelem życia a znaczeniem życia rodzinnego
}

\author{
Contemporary family - dissonance \\ between the preferred life model \\ and the importance of family life
}

\begin{abstract}
In the work the chosen aspect of sociological empirical research, carried out among the students of the Constantine the Philosopher University in Nitra and among students of the University of Silesia in Katowice, concerned their opinion on family life in the
\end{abstract}

contemporary world and their preferred model of life and plans concerning marriage in the future.

Keywords: cohabitation, family, marriage

Przemiany, jakim podlega życie rodzinne ${ }^{1}$, przyjmują coraz większe rozmiary, obejmując swym zasięgiem nie tylko sposoby myślenia o rodzinie, ale przede wszystkim dynamikę zmiany kształtu czy też sposobu formowania rodziny.

Zob. A. Kwak, Rodzina $w$ dobie przemian. Małżeństwo i kohabitacja, Warszawa 2005; K. Slany, Alternatywne formy życia małżeńsko-rodzinnego w ponowoczesnym świecie, Kraków, 2006; Z. Tyszka, Rodzina we współczesnym świecie, Poznań 2002; Z. Tyszka, Rodzina współczesna - jej geneza i kierunki przemian, [w:] Rodzina współczesna, red. M. Ziemska, Warszawa 2001; T. Szlendak, Socjologia rodziny. Ewolucja, historia, zróżnicowanie, Warszawa 2010. 
Zmiany obejmują także ludzki świat wartości, który w dużym stopniu przyczynia się do kształtowania podejmowanych decyzji na różnym szczeblu budowania lub reorganizowania rodziny, niezależnie od regionalnych zróżnicowań warunków życia. Współczesna rodzina kurczy się jako najmniejsza, a zarazem najważniejsza cząstka życia społecznego ${ }^{2}$. Obecnie przemiany te dotyczą nie tylko struktury rodzin, ale również pozycji i roli kobiety oraz mężczyzny w rodzinie. Zmiany więzi i relacji między partnerami czy małżonkami zorientowane są na ich wysoką osobową jakość, wynikają bowiem z postępującego procesu indywidualizacji życia jednostek, które w coraz większym stopniu podejmują działania zorientowane na siebie, $\mathrm{z}$ naciskiem na autonomię, samorealizację i zaspokojenie potrzeb emocjonalnych oraz seksualnych, a w tle również materialnych ${ }^{3}$.

Kształt i funkcjonowanie rodziny, jak pisze Zbigniew Tyszka ${ }^{4}$, zależą w sposób istotny także od „reszty” świata społecznego, zewnętrznego w stosunku do rodziny. Społeczeństwo globalne, a ściślej rzecz ujmując, któreś z jego stadiów rozwojowych (społeczeństwo preindustrialne, industrialne i postindustrialne), wraz z zawartymi w nim zhierarchizowanymi układami społecznymi, wpływa na rodzinę, odpowiednio modyfikując ją i jej subsystemy, a z kolei modyfikowana rodzina wywiera podlegające przekształceniom wpływy na społeczeństwo globalne, jego substruktury i procesy. Te interakcyjne oddziaływania z kolei intensyfikują się w okresach szybszych przeobrażeń społeczeństwa. Rodzina jest więc istotnym elementem społecznych interakcji.

Artykuł oparty jest na badaniach przeprowadzonych wśród studentów z Uniwersytetu Konstantyna Filozofa w Nitrze na Słowacji i Uniwersytetu Śląskiego w Katowicach. Badania zostały przeprowadzone na próbie badawczej liczącej 1237 studentów. Podstawowym narzędziem badawczym wykorzystanym w badaniach był kwestionariusz ankiety ${ }^{5}$ zawierający 43 pytania.

Opinie studentów jako kategorii socjologicznej są bardzo istotne, kiedy mamy na uwadze życie rodzinne. Po pierwsze, stanowią oni warstwę wzorcotwórczą (grupę odniesienia porównawczego) dla pokolenia swoich rówieśników. Po drugie, studenci są pod najsilniejszą presją kultury ponowoczesnej i jej zindywidualizowanych wzorów samorealizacji. Także w tym środowisku społecznym plany na przyszłość dotyczące wyboru formy życia małżeńsko-rodzinnego

\footnotetext{
2 W. Świątkiewicz, Rodzina w województwie katowickim. Opracowania i raport, Katowice 1998, s. 10.

3 K. Juszczyk-Frelkiewicz, Kohabitacja w Polsce i na Stowacji. Studium socjologiczne w środowiskach studenckich, Katowice 2014, s. 9.

4 Z. Tyszka, Rodzina we współczesnym świecie, Poznań 2002, s. 14.

5 Zob. L. A. Gruszczyński, Kwestionariusze w socjologii. Budowa narzędzi do badań surveyowych, Katowice 1999.
} 
Wykres 1. Preferowana forma związku a kraj

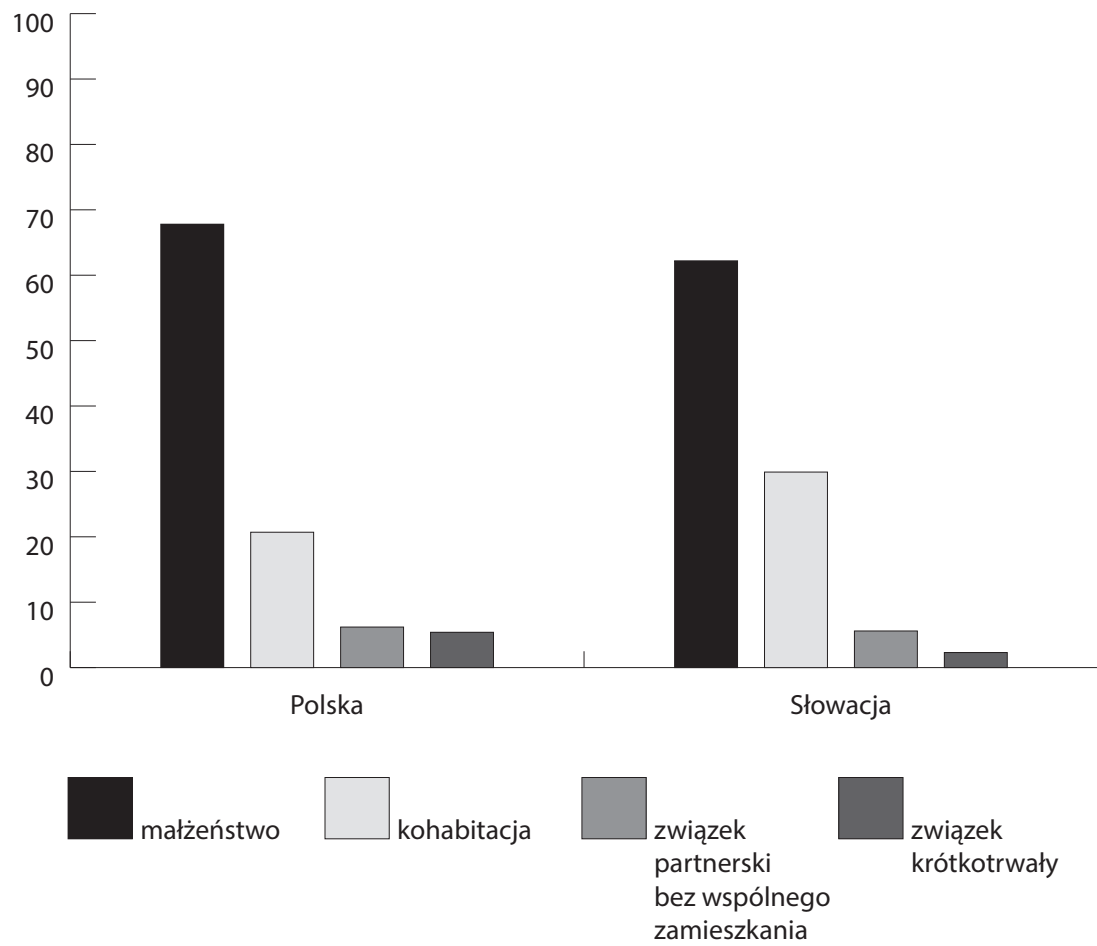

Źródło: badania własne.

oraz formułowane opinie na temat znaczenia życia rodzinnego we współczesnym świecie wiążą się ściśle z najnowszymi formami kształtowania więzi rodzinnych i partnerskich oraz z kierunkami rozwoju zjawiska kohabitacji ${ }^{6}$.

Analiza przeprowadzonych badań ukazuje dysonans pomiędzy modelem życia preferowanym przez studentów a znaczeniem życia rodzinnego we współczesnym świecie. Większość badanych studentów z Polski $(67,8 \%)$ i ze Słowacji $(62,2 \%)$ preferowało małżeństwo jako formę związku najwłaściwszą dla siebie. Jedna piąta studentów z Polski (20,7\%) oraz jedna trzecia studentów ze Słowacji $(29,9 \%)$ wybrała kohabitację twierdząc, że taki rodzaj związku najbardziej by im odpowiadał (zob. wykres 1.). Analiza wskazuje na duże różnice statystyczne między studentami z Polski i Słowacji w kwestii wskazania preferowanej formy życia w przyszłości - p<0,05 (wynik testu $\chi^{2}=19,389 ; \mathrm{p}=0,000$ ).

$\mathrm{Z}$ analizy badań wynika, że małżeństwo jest bardziej preferowane przez kobiety (68,9\%) niżeli przez mężczyzn (59,8\%). Związek kohabitacyjny został

6 Zob. K. Juszczyk-Frelkiewicz, Kohabitacja w Polsce i na Słowacji..., dz. cyt. 
wybrany przez jedną czwartą kobiet (25,3\%) i mężczyzn (25,0\%). Analiza ukazuje duże różnice statystyczne między kobietami i mężczyznami co do preferowanej formy życia - $\mathrm{p}<0,05$ (wynik testu $\chi^{2}=18,032 ; \mathrm{p}=0,000$ ) (zob. wykres 2.). Wynikać to może z faktu, iż kobiety chcą żyć w związku stabilnym, trwałym, a takim związkiem jest małżeństwo - nawet jeżeli obecnie w rzeczywistości społecznej występuje wzrost rozwodów i instytucja małżeństwa jawi się jako mało stabilna, to w porównaniu ze związkiem kohabitacyjnym, który zazwyczaj jest krótkotrwałym związkiem o małej stabilności, małżeństwo odznacza się większą trwałością. Podkreślić jednak należy, że w świecie współczesnym coraz więcej młodych ludzi decyduje się na życie w kohabitacji, która w większym stopniu umożliwia partnerom większy stopień autonomii, samorealizacji.

Z badań wynika także, że im wyższa częstotliwość udziału w praktykach religijnych, tym wyższy odsetek studentów wskazujących, iż małżeństwo jest preferowanym modelem związku na przyszłość. Małżeństwo zostało wskazane przez ponad $80 \%$ studentów, którzy uczestniczyli w mszach świętych kilka razy w tygodniu $(88,1 \%)$ lub raz w tygodniu $(85,8 \%)$. Z badań wynika, iż studenci, którzy odznaczali się absencją religijną, także często (bo prawie co drugi student - 46,6\%) wybierali związek małżeński. Należy zwrócić uwagę na fakt, że im rzadszy udział w praktykach religijnych, tym częstszy wybór przez respondentów związku kohabitacyjnego - w ten sposób wskazywało prawie $40 \%$ studentów niebiorących udziału w praktykach religijnych, którzy byli podzieleni $\mathrm{w}$ tej kwestii, ponieważ ponad $46 \% \mathrm{z}$ nich preferowało stabilniejszy związek małżeński (zob. tabela 1.). Analiza wskazuje na istotne statystycznie różnice zachodzące między częstotliwością udziału w praktykach religijnych a preferowaną formą życia na przyszłość - p<0,05 (wynik testu $\left.\chi^{2}=136,314 ; \mathrm{p}=0,000\right)$.

Miejsce zamieszkania okazało się zmienną niezależną, która nie różnicuje preferowanej formy życia studentów w przyszłości - p>0,05 (wynik testu $\chi^{2}=13,181 ; p=0,103$ ). Zatem niezależnie od miejsca zamieszkania, $w$ dużym lub małym mieście oraz na wsi ponad $60 \%$ studentów wybrało związek małżeński. Podobnie sytuacja przedstawia się co do wyboru związku kohabitacyjnego przybliżony odsetek respondentów wskazywał na ten model życia jako najwłaściwszy dla siebie (zob. tabela 2.).

Niezależnie od: kraju zamieszkania studentów, płci, miejsca zamieszkania oraz częstotliwości udziału w mszach świętych, studenci preferowali małżeństwo jako formę związku najwłaściwszą dla nich samych w przyszłości. Taki wybór studentów świadczy o tym, iż insty tucja małżeństwa ma dla nich duże znaczenie i większość młodych ludzi będzie aranżować swoje życie właśnie w związku małżeńskim. Wybór związku kohabitacyjnego przez jedną czwar- 
Wykres 2. Preferowana forma związku a płeć

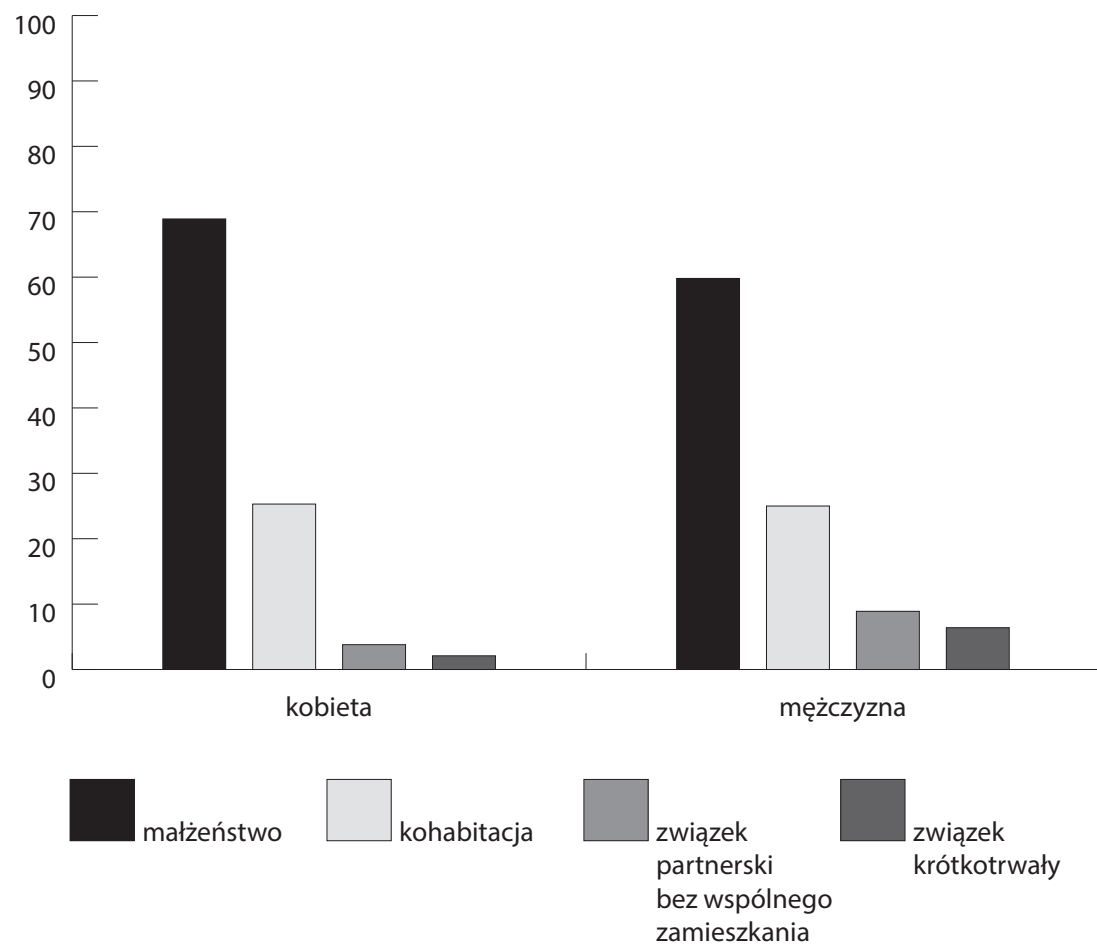

Źródło: badania własne.

tą respondentów (25,1\%), może świadczyć o tym, że część młodych ludzi podąża w kierunku liberalnych wartości i zachowań, które coraz częściej spotykają się z aprobatą społeczną. Jednak należy pamiętać, że kohabitacja nie stanowi tylko i wyłącznie alternatywy dla małżeństwa, ale może być też wstępem do niego. Dlatego można zakładać, że większość studentów, która w przyszłości wstąpi w związek kohabitacyjny, po pewnym czasie przekształci go w związek małżeński.

Studenci w ankiecie zostali także zapytani, czy zamierzają zawrzeć związek małżeński w przyszłości; było to pytanie kontrolne, które miało potwierdzać plany badanej społeczności akademickiej związane z małżeństwem.

Analiza wyników badań wskazuje, iż studenci z Polski $(70,8 \%)$ i Słowacji $(77,1 \%)$ mieli w planach na przyszłość zawarcie małżeństwa. Należy podkreślić, iż bardziej zdecydowani - o niecałe 10 punktów procentowych - w tej kwestii byli studenci ze Słowacji niżeli z Polski. Sytuacja ta jest zaskakująca, ponieważ społeczeństwo słowackie jest zdecydowanie bardziej liberalne i w wyższym stopniu uznaje wartości świecko-racjonalne niż społeczeństwo polskie, któ- 


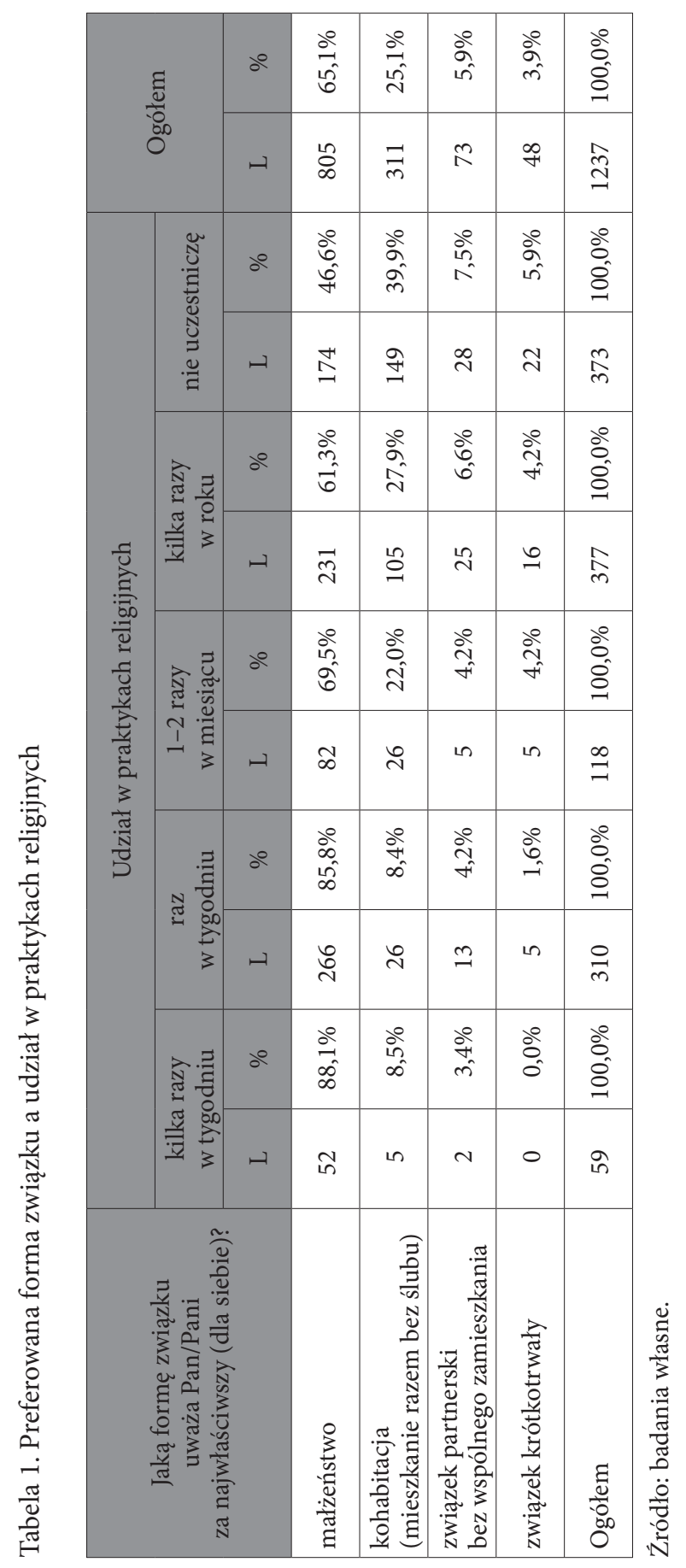




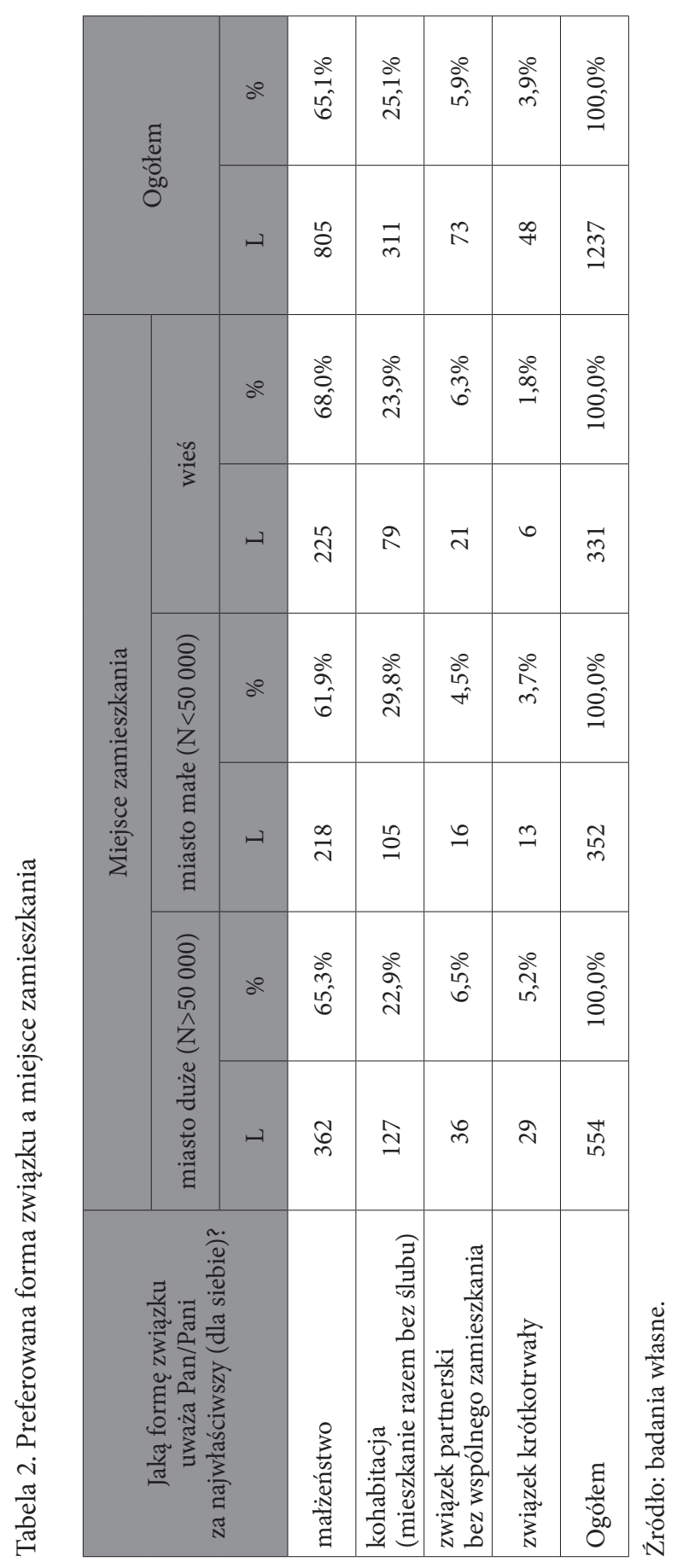


Wykres 3. Plany dotycząca zawarcia małżeństwa w przyszłości a kraj

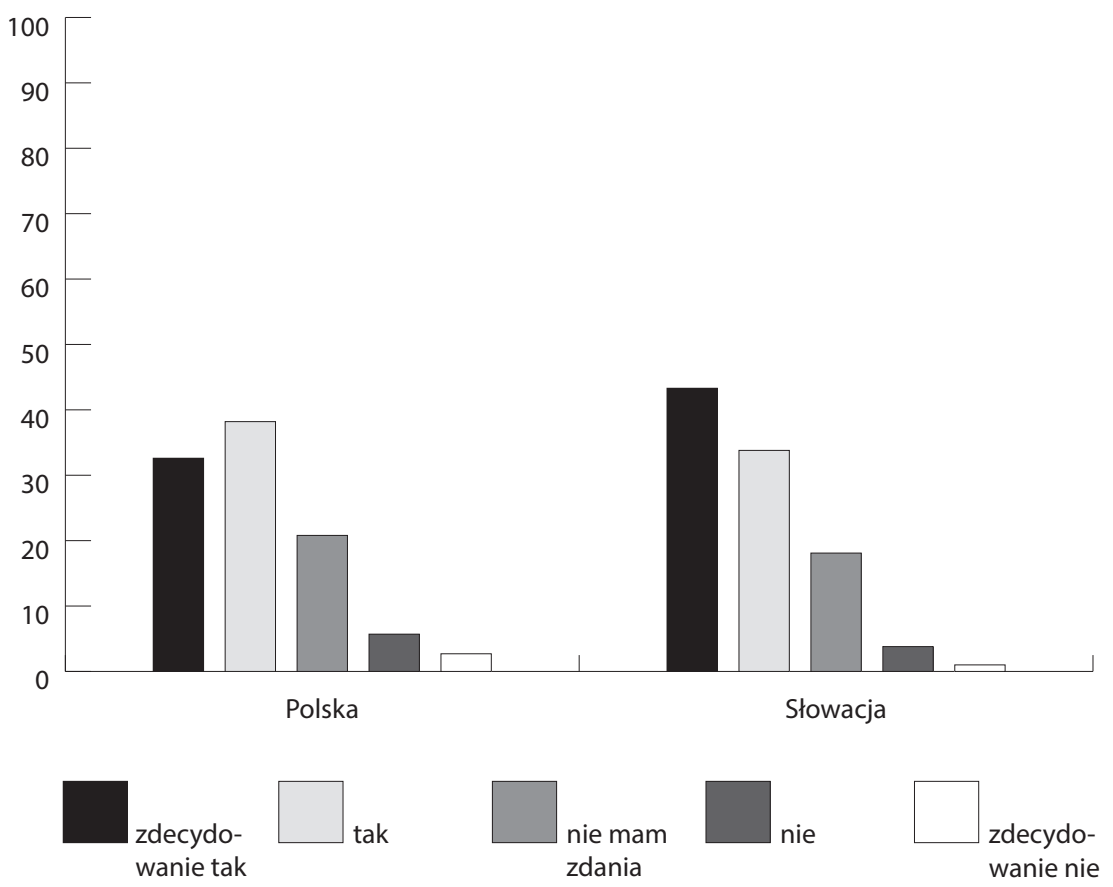

Źródło: badania własne.

re jest bardziej tradycyjne ${ }^{7}$ - zatem można by się było spodziewać sytuacji odwrotnej. Należy również zwrócić uwagę na odsetek respondentów, którzy wahali się i nie wiedzieli, jaką formę życia wybiorą w przyszłości - jedna piąta studentów nie miała zdania w tej kwestii. Analiza wskazuje na istotne statystycznie różnice między studentami z Polski i Słowacji - p $<0,05$ (wynik testu $\chi^{2}=19,024$; $\mathrm{p}=0,001$ ) (zob. wykres 3.).

Z badań wynika, że więcej kobiet $(77,9 \%)$ niż mężczyzn $(68,2 \%)$ zamierza zawrzeć związek małżeński w przyszłości. Z kolei więcej mężczyzn $(24,4 \%)$ nie ma zdania w tej kwestii. Kobiety w swych deklaracjach dotyczących zawarcia małżeństwa w przyszłości są bardziej zdecydowane niż mężczyźni. Może to wynikać z faktu, iż pragną stworzyć w przyszłości stabilny związek, oparty na miłości, zaufaniu, wsparciu i fundamentalnym umocnieniu poprzez zawarcie mał-

7 R. Inglehart, Ch. Wenzel, Modernization, Cultural Change and Democracy. The Human Development Sequence, New York-Cambridge 2005, s. 63, za: P. Zdziech, Ronalda Ingleharta teoria rozwoju ludzkiego, Kraków 2010, s. 72. 
Wykres 4. Plany dotycząca zawarcia małżeństwa w przyszłości a płeć

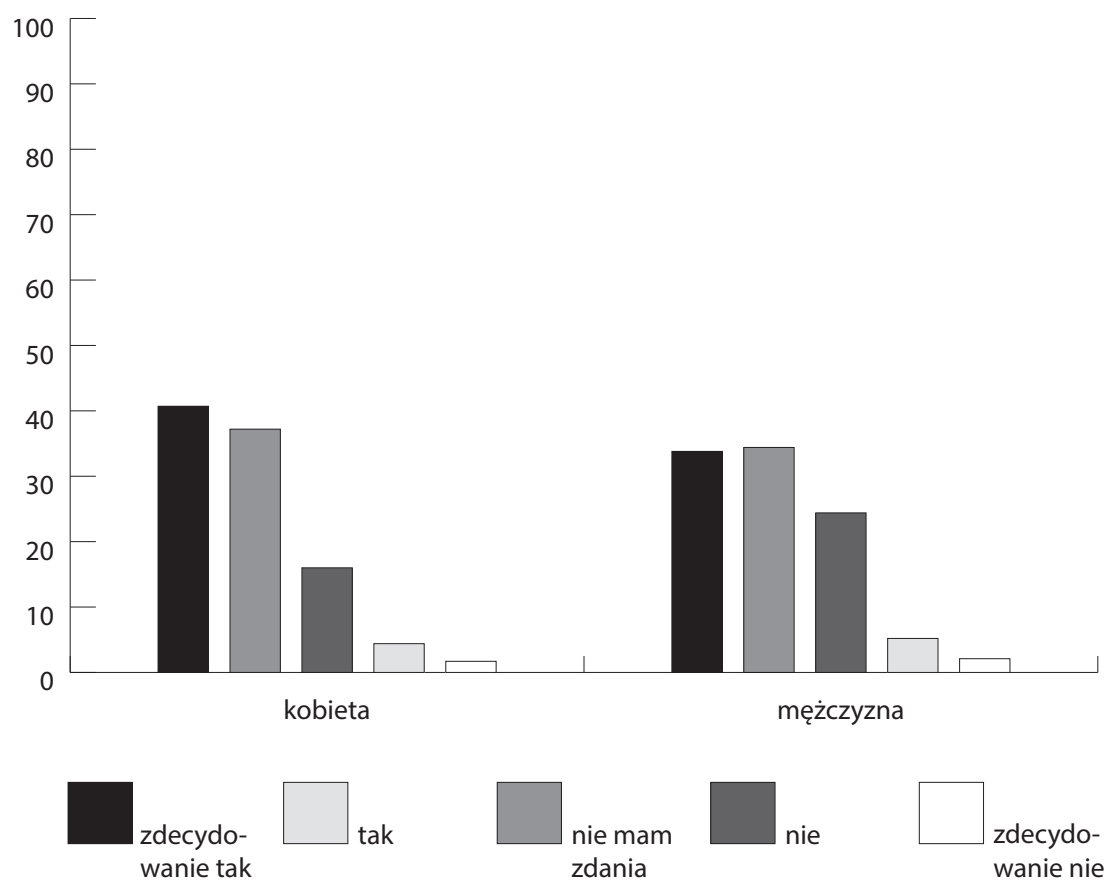

Źródło: badania własne.

żeństwa cywilnego bądź konkordatowego. Analiza wskazuje, iż między badanymi płciami występują różnice statystyczne $-\mathrm{p}<0,05$ (wynik testu $\chi^{2}=16,000$; $\mathrm{p}=0,003)$ (zob. wykres 4.).

Analiza badań wskazuje także, że im częściej studenci brali udział w praktykach religijnych, tym większy odsetek z nich posiadał plany związane z zawarciem związku małżeńskiego w przyszłości. Studenci, którzy odznaczali się absencją religijną, także w większości mieli w planach przyszłościowych związek małżeński, jednak jedna trzecia z nich $(31,6 \%)$ nie posiadała ukierunkowanych planów na przyszłość, co do formy związku. Analiza wskazuje, iż występują istotne statystycznie różnice między częstotliwością udziału w praktykach religijnych a planami związanymi z zawarciem małżeństwa $\mathrm{p}<0,05$ (wynik testu $\left.\chi^{2}=121,650 ; \mathrm{p}=0,000\right)$ (zob. tabela 3.).

Około 60\% studentów niezależnie od płci, kraju zamieszkania, miejsca zamieszkania, częstotliwości udziału w praktykach religijnych preferowało małżeństwo jako rodzaj związku najwłaściwszy dla siebie. Tę preferencję potwierdził fakt, iż zawarcie związku małżeńskiego występuje w planach na 


\begin{tabular}{|c|c|c|c|c|c|c|c|c|}
\hline \multirow{2}{*}{\multicolumn{2}{|c|}{ 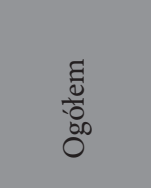 }} & $\alpha^{\circ}$ & $\begin{array}{l}\text { oे } \\
\infty \\
\hat{m}\end{array}$ & $\frac{\circ}{\sigma^{0}}$ & $\begin{array}{l}\text { oे } \\
\text { in } \\
\stackrel{-}{=}\end{array}$ & $\begin{array}{l}\stackrel{0}{\infty} \\
\infty\end{array}$ & $\stackrel{\circ}{\Leftrightarrow}$ & $\begin{array}{l}\circ \\
\AA_{0}^{\circ} \\
\stackrel{0}{0}\end{array}$ \\
\hline & & $\mapsto$ & $\underset{f}{\infty}$ & $\stackrel{b}{\not}$ & $\underset{\mathrm{J}}{\mathrm{J}}$ & ถે & $\ddot{\sim}$ & $\hat{\sim}$ \\
\hline \multirow{10}{*}{ 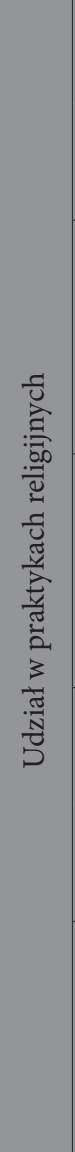 } & \multirow{2}{*}{ 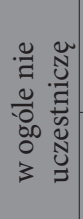 } & $d^{0}$ & 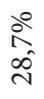 & $\begin{array}{l}\text { i̊ } \\
\text { in }\end{array}$ & $\underset{\vec{m}}{\stackrel{0}{0}}$ & $\begin{array}{l}\stackrel{0}{0} \\
\infty\end{array}$ & $\stackrel{8}{\circ}$ & $\begin{array}{l}\circ \\
8 \\
8\end{array}$ \\
\hline & & $\mapsto$ & $\hat{\circ}$ & $\stackrel{\varrho}{0}$ & $\stackrel{\infty}{=}$ & ిల & $\stackrel{n}{=}$ & $\stackrel{m}{m}$ \\
\hline & \multirow{2}{*}{ 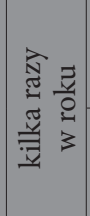 } & $\alpha^{\circ}$ & $\begin{array}{l}\stackrel{0}{1} \\
\infty \hat{n}^{2} \\
\end{array}$ & $\begin{array}{l}\text { oे } \\
\text { ஸे } \\
\text { के }\end{array}$ & $\begin{array}{l}\delta^{\circ} \\
\stackrel{-}{-}\end{array}$ & $\begin{array}{l}\stackrel{े}{े} \\
\text { مे }\end{array}$ & $\stackrel{\circ}{\Rightarrow}$ & $\begin{array}{l}0 \\
8 \\
8 \\
8\end{array}$ \\
\hline & & $\dashv$ & $\stackrel{ }{\stackrel{0}{1}}$ & กิ & ఫु & $\exists$ & 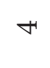 & 命 \\
\hline & \multirow{2}{*}{ 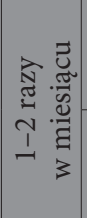 } & $d^{\circ}$ & $\begin{array}{l}\stackrel{\circ}{N} \\
\stackrel{m}{m}\end{array}$ & $\begin{array}{l}\delta_{0} \\
\text { के }\end{array}$ & $\begin{array}{l}\dot{b}_{0}^{0} \\
\hat{n}\end{array}$ & $\stackrel{\stackrel{0}{0}}{\hat{O}^{2}}$ & $\begin{array}{l}\text { in } \\
\text { in }\end{array}$ & $\begin{array}{l}\circ \\
8 \\
8 \\
8\end{array}$ \\
\hline & & $\mapsto$ & F & \& & $\mathscr{0}$ & 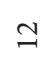 & $m$ & $\stackrel{\infty}{=}$ \\
\hline & \multirow{2}{*}{ 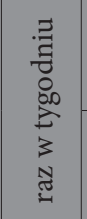 } & $\therefore$ & $\begin{array}{l}\stackrel{\circ}{1} \\
\stackrel{\text { in }}{f}\end{array}$ & $\begin{array}{l}\stackrel{\circ}{\tilde{m}} \\
\stackrel{f}{f}\end{array}$ & $\stackrel{8}{b_{0}^{0}}$ & $\stackrel{\circ}{\stackrel{\circ}{\rightarrow}}$ & $\begin{array}{c}\text { के } \\
\text { के }\end{array}$ & $\begin{array}{l}\circ \\
8 \\
8 \\
8\end{array}$ \\
\hline & & 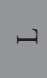 & $\stackrel{\infty}{\sim}$ & $\vec{n}$ & $\stackrel{m}{n}$ & 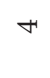 & - & $\stackrel{\circ}{m}$ \\
\hline & \multirow{2}{*}{ 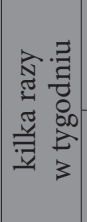 } & $\partial^{\circ}$ & $\frac{\stackrel{\circ}{0}}{\hat{\sigma}}$ & $\begin{array}{l}\stackrel{\circ}{\hat{N}} \\
\stackrel{\lambda}{\lambda}\end{array}$ & $\stackrel{\text { बे }}{=}$ & $\stackrel{\circ}{\stackrel{\circ}{n}}$ & $\begin{array}{l}\circ \\
\stackrel{0}{0} \\
0\end{array}$ & $\begin{array}{l}\stackrel{0}{0} \\
\stackrel{8}{0}\end{array}$ \\
\hline & & $\dashv$ & r & $\Xi$ & $\wedge$ & $N$ & 0 & in \\
\hline \multicolumn{2}{|r|}{ 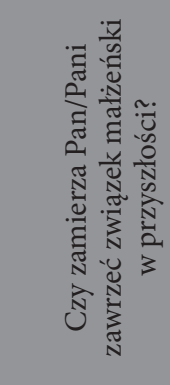 } & & 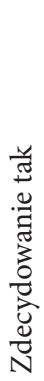 & 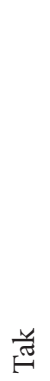 & 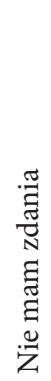 & $\stackrel{\oplus}{Z}$ & 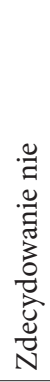 & $\begin{array}{l}\text { हี } \\
\overline{0} \\
0 \\
0\end{array}$ \\
\hline
\end{tabular}


przyszłość większości respondentów. Jednak badani studenci twierdzili również, iż współcześnie życie rodzinne ma coraz mniejsze znaczenie - stwierdziło tak ok. 46,6\%, co świadczy o dysonansie występującym pomiędzy preferowaną przez studentów formą życia w małżeństwie a opinią na temat życia rodzinnego.

Analiza badań wskazuje, iż studenci z Polski (54,4\%) częściej niż studenci ze Słowacji $(38,3 \%)$ wyrażali opinię, że współcześnie życie rodzinne ma coraz mniejsze znaczenie. Z kolei więcej respondentów ze Słowacji (20,4\%) niż z Polski $(7,3 \%)$ stwierdziło, że życie rodzinne ma coraz większe znaczenie. Analiza wskazuje na statystyczne różnice między krajem zamieszkania studentów a ich opinią na temat życia rodzinnego $-p<0,05$ (wynik testu $\chi 2=60,578 ; p=0,000)$ (zob. wykres 5.). Kolejny raz sytuacja jest nietypowa $z$ uwagi na fakt, że społeczeństwo polskie uznaje w większości tradycyjne wartości i rodzina jest najważniejszą instytucją społeczną - badani studenci wydają się być pod wpływem liberalnych wartości. Tylko 7,3\% ankietowanych z Polski wyrażało opinię, że życie rodzinne

Wykres 5. Opinia na temat życia rodzinnego we współczesnym społeczeństwie a kraj

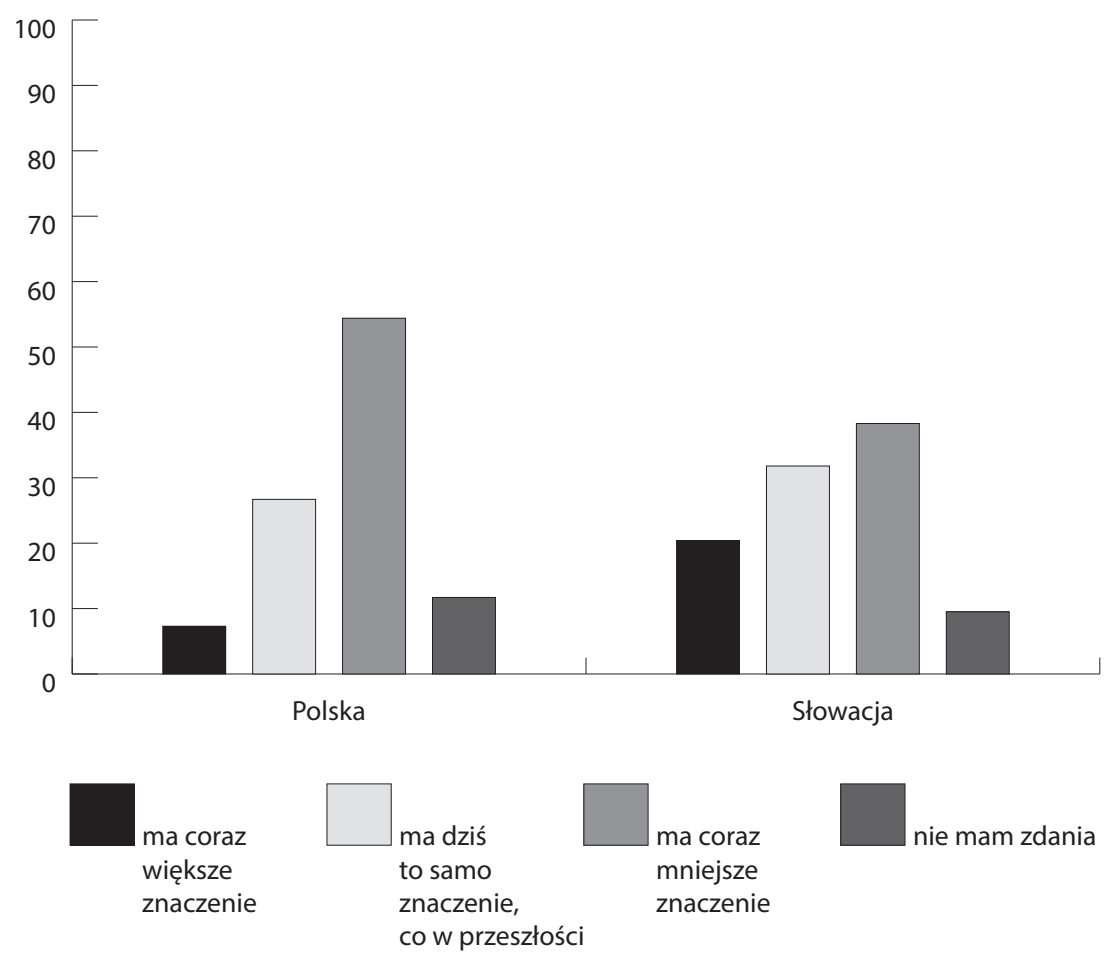

Źródło: badania własne. 
ma coraz większe znaczenie. Przyczyn takiej sytuacji może być wiele. Na mniejsze znaczenie rodziny we współczesnym świecie według studentów z Polski może wpływać dyfuzja liberalnych wartości z krajów Europy zachodniej, sekularyzacja społeczeństwa, brak: faktycznie wspierającej rodzinę i młodych ludzi polityki rodzinnej, która zapewniłaby stabilność życia rodzinnego w sprawach ekonomicznych; zapewnienia młodym ludziom stabilnych warunków zatrudnienia oraz wyższego uposażenia; wprowadzenia jeszcze dłuższych, płatnych urlopów macierzyńskich; czy też wprowadzenia płatnych urlopów wychowawczych. Polityka rodzinna w Polsce nie sprzyja młodym ludziom, co powoduje konieczność poświęcania przez nich więcej czasu na naukę, pracę, samorealizację - niestety, kosztem życia rodzinnego.

Badania wskazują, iż płeć istotnie statystycznie różnicuje opinie badanych studentów na temat życia rodzinnego $-\mathrm{p}<0,05$ (wynik testu $\chi^{2}=18,032 ; \mathrm{p}=0,000$ ). Badane kobiety (49,0\%) znacznie częściej niż badani mężczyźni (43,1\%) wskazywały, iż życie rodzinne ma coraz mniejsze znaczenie. Z kolei więcej mężczyzn

Wykres 6. Opinia na temat życia rodzinnego we współczesnym społeczeństwie a płeć

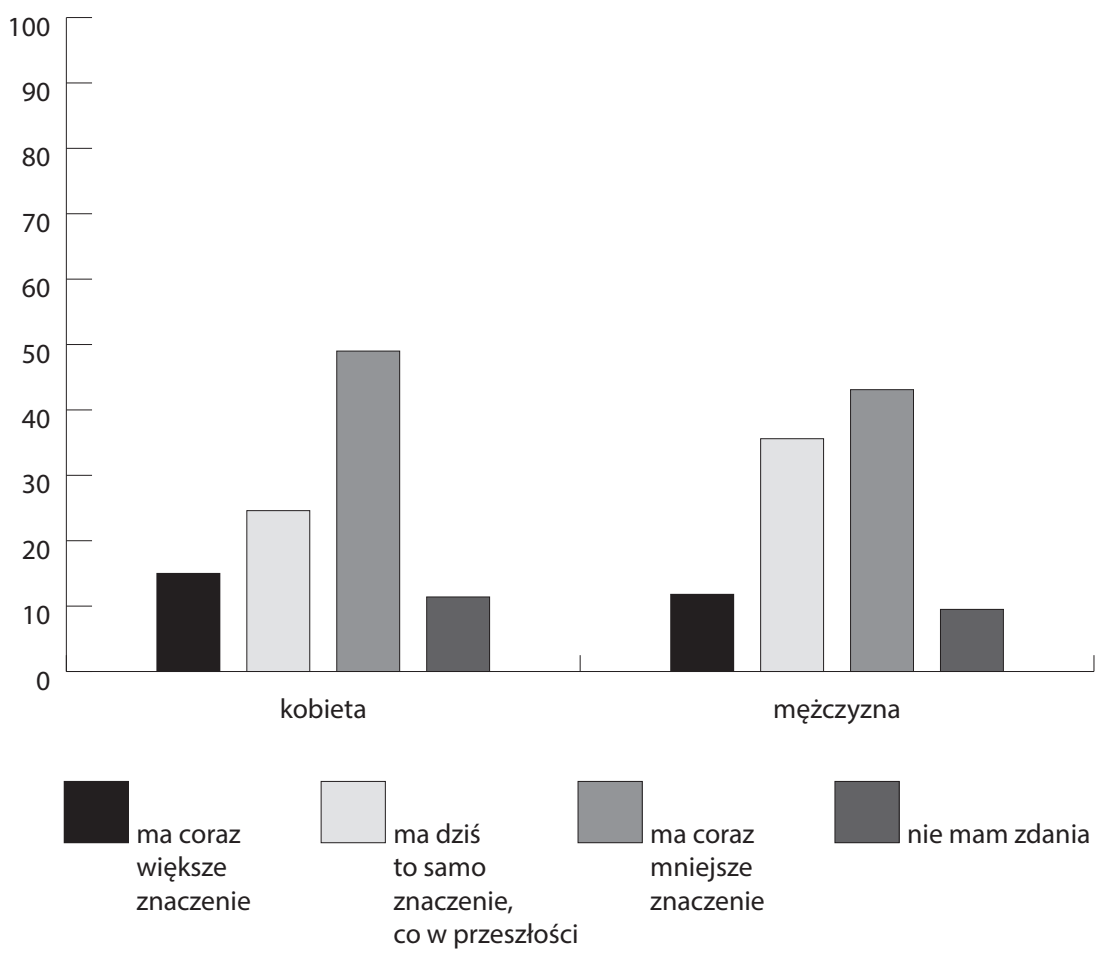

Źródło: badania własne. 
$(35,6 \%)$ niż kobiet było zdania, że rodzina ma to samo znaczenie co w przeszłości (zob. wykres 6.).

Wiek badanych respondentów także okazuje się zmienną niezależną, która istotnie statystycznie różnicuje opinie studentów na temat życia rodzinnego $\mathrm{p}<0,05$ (wynik testu $\chi^{2}=17,426 ; \mathrm{p}=0,008$ ). $Z$ analizy wynika, że w wyższych kategoriach wiekowych - 20 do 22 lata $(49,4 \%)$ oraz 23 do 25 lat $(47,1 \%)$ - respondenci posiadali w większości opinię, iż życie rodzinne ma coraz mniejsze znaczenie. Natomiast studenci z kategorii wiekowej między 18. a 19. rokiem życia byli podzieleni na dwie grupy. Pierwsza z nich stwierdziła, że życie rodzinne ma to samo znaczenie co w przeszłości $(36,8 \%)$, natomiast druga grupa twierdziła, że życie rodzinne ma coraz mniejsze znaczenie - studentów, którzy tak twierdzili, było 35,3\% (zob. wykres 7.).

Analiza wyników badań wskazuje, iż opinie na temat znaczenia życia rodzinnego są różnicowane przez miejsce zamieszkania badanych studentów $\mathrm{p}<0,05$ (wynik testu $\chi^{2}=24,971 ; \mathrm{p}=0,000$ ). Wyższy odsetek studentów mieszkają-

Wykres 7. Opinia na temat życia rodzinnego we współczesnym społeczeństwie a wiek

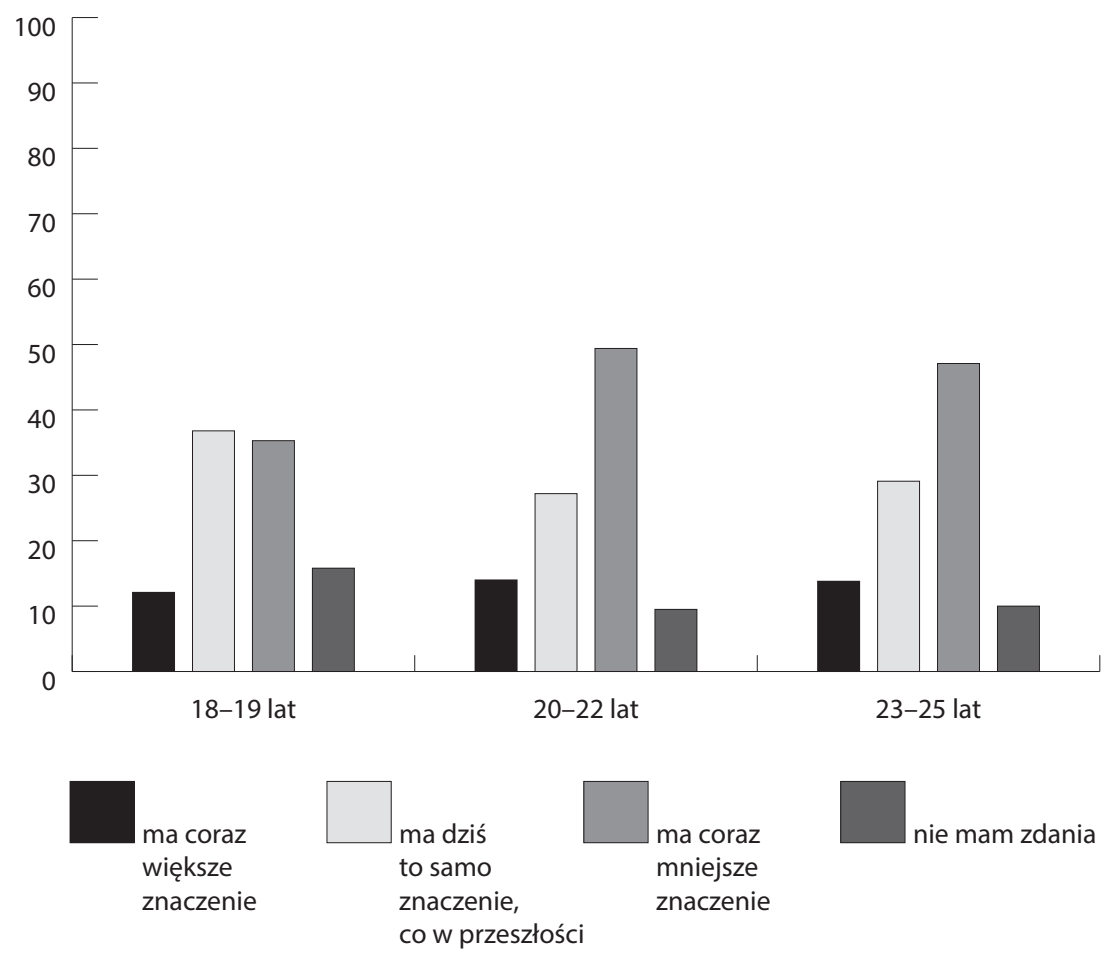

Źródło: badania własne. 
Wykres 8. Opinia na temat życia rodzinnego we współczesnym społeczeństwie a miejsce zamieszkania

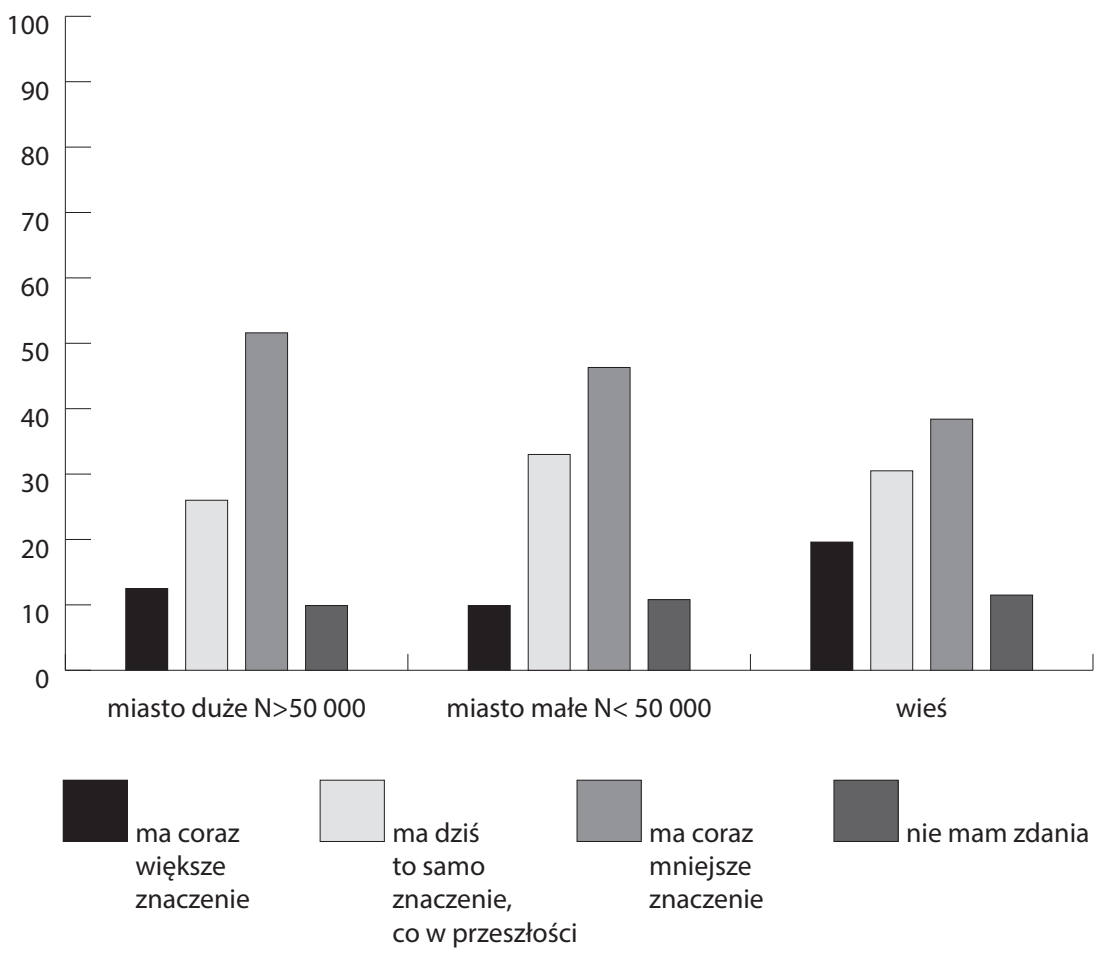

Źródło: badania własne.

cych w dużym mieście (51,6\%) lub w małym mieście (46,3\%) stwierdził, iż życie rodzinne ma mniejsze znaczenie, niż w przeszłości. $Z$ kolei studenci mieszkający na wsi nie byli zdecydowani w tej kwestii. Część z nich była takiego samego zdania jak mieszkańcy miast, którzy deklarowali, iż życie rodzinne ma coraz mniejsze znaczenie $(38,4 \%)$, a część twierdziła, iż rodzina ma takie samo znaczenie jak w przeszłości (30,5\%) (zob. wykres 8.).

Rozwój gospodarki w Polsce i na Słowacji, a także w innych krajach Europy (szczególnie Europy zachodniej), krajach skandynawskich i Stanach Zjednoczonych oraz ciągle postępujące procesy industrializacji, informatyzacji i urbanizacji, zmniejszające się przywiązanie do wartości religijnych oraz tradycji powodują, że przemiany, jakie dokonują się w rodzinie i życiu rodzinnym, będą wykazywały charakter ciągły. Im bardziej społeczeństwo będzie zurbanizowane i zindustrializowane, tym większe zmiany (bardziej liberalne i nastawione indywidualistycznie, wolnościowo - możliwość wyboru) będziemy obserwować. Wzrost liczby rozwodów na przestrzeni ostatnich 
lat ${ }^{8}$, który świadczy o coraz mniejszej stabilności małżeństwa, także wpływa na opinie społeczne dotyczące życia rodzinnego. Wzrost liczby osób żyjących w związku kohabitacyjnym ${ }^{9}$ świadczy o tym, że młodzi ludzie coraz częściej zaczynają aranżować swoje życie w formie innej niż małżeństwo z uwagi na korzyści, jakie niesie ze sobą życie w kohabitacji (większa autonomia, większe możliwości samorealizacji, niezależność finansowa etc.). Niewątpliwie ukazany w badaniach dysonans między preferowaną formą życia w małżeństwie a opinią na temat życia rodzinnego - iż ma ono coraz mniejsze znaczenie - jest wynikiem postępującego w Polsce i na Słowacji procesu indywidualizacji, sekularyzacji, nastawienia na samorealizację i chęciosiągnięcia sukcesów w życiu zawodowym.

\section{Bibliografia}

Gruszczyński L. A., Kwestionariusze w socjologii. Budowa narzędzi do badań surveyowych, Katowice 1999.

Juszczyk-Frelkiewicz K., Kohabitacja w Polsce i na Słowacji. Studium socjologiczne w środowiskach studenckich, Katowice 2014.

Kwak A., Rodzina w dobie przemian. Małżeństwo i kohabitacja, Warszawa 2005.

Rocznik Demograficzny, GUS, Warszawa 2014.

Slany K., Alternatywne formy życia małżeńsko-rodzinnego w ponowoczesnym świecie, Kraków 2006.

Szlendak T., Socjologia rodziny. Ewolucja, historia, zróżnicowanie, Warszawa 2010.

Świątkiewicz W., Rodzina w województwie katowickim. Opracowania i raport, Katowice1998. Tyszka Z., Rodzina we współczesnym świecie, Poznań 2002.

Tyszka Z., Rodzina współczesna - jej geneza i kierunki przemian, [w:] Rodzina współczesna, red. M. Ziemska, Warszawa 2001.

8 GUS, Rocznik Demograficzny, Warszawa 2014, s. 280.

9 Tamże, s. 165. 
A. Uniwersytet Papieski T.5. Jana Pawła II 